\title{
Gelatin fragments block adherence of Candida albicans to extracellular matrix proteins
}

\author{
Stephen A. Klotz ${ }^{1,2}$ and Robert L. Smith ${ }^{3}$ \\ Author for correspondence: Stephen A. Klotz. Fax: +1 8168611110.
}

1 Departments of Medicine, Microbiology and Immunology, University of Kansas School of Medicine, Kansas City, KS 64128, USA

2 Research Service, Veterans Affairs Medical Center, 4801 Linwood Blvd, Kansas City, MO 64128, USA

3 Department of Biochemistry and Molecular Biology, Louisiana State University School of Medicine at Shreveport, Shreveport, LA 71130, USA

\begin{abstract}
The adherence of Candida albicans to extracellular matrix proteins may be a critical step in the pathogenesis of candidiasis. Yeast cell adherence to type I and IV collagen, fibronectin and laminin was blocked by peptide fragments from denatured type I collagen (gelatin). Gelatin fragments were obtained by digestion of the reduced protein with trypsin or CNBr. The fragments did not have antifungal properties, presumably inhibiting adherence by blocking receptors (adhesins) on the surface of the fungus. A 10-mer (GQRGVVGLPG) fashioned from the $\alpha-1$ chain of type I collagen reduced adherence by $68 \%$. However, a gelatin peptide possessing 47 amino acids reduced fungal adherence to type I collagen by $100 \%$. Peptides derived from the biocompatible protein gelatin, therefore, may have a potential role in reducing the adherence of the fungus to host proteins.
\end{abstract}

Keywords: Candida, extracellular matrix, adherence, peptides, gelatin

\section{INTRODUCTION}

The adherence of Candida albicans to host tissue is presumed to be a critical and necessary step in the pathogenesis of all forms of candidiasis, including the gravest manifestation of the disease, disseminated candidiasis (Calderone \& Braun, 1991 ; Klotz, 1992). One of the fungal targets for adherence in candidiasis may be proteins of the extracellular matrix (ECM) (Klotz, 1992). Since adherence is a necessary step in the establishment of disease by $C$. albicans, it follows that preventing or interrupting adherence may ameliorate or abrogate disease. In this report we show that gelatin fragments inhibit or block the adherence of $C$. albicans yeast cells to ECM proteins.

Gelatin contains primarily the denatured form of type I collagen, a glycoprotein which, along with fibronectin, laminin, and type IV collagen, may constitute some of the adherence targets of bloodborne yeast cells in disseminated candidiasis (Klotz, 1992). These ECM glycoproteins may serve as targets for adherence in mucosal and skin infections with this fungus as well. For example, $C$. albicans binds avidly to the ECM proteins type I and IV collagen, laminin and fibronectin when these glycoproteins are immobilized on plastic surfaces (Klotz, 1990). Furthermore, the fungus binds soluble fibronectin and in

Abbreviation: ECM, extracellular matrix. doing so prevents fungal adhesion to immobilized ECM proteins and basement membrane (Klotz \& Smith, 1991). Previous work has shown that the adherence of $C$. albicans yeast cells to immobilized ECM proteins and to subendothelial ECM is also inhibited by peptides derived from fibronectin, such as RGD, or from collagen, such as GRGESP (Klotz \& Smith, 1991).

Gelatin is a protein available in large quantities which is tolerated by humans even when given intravenously (Adelmann-Grill, 1981). Gelatin contains both RGD and RGE sequences and therefore may yield fragments containing these sequences which possess inhibitory activity against $C$. albicans adherence to ECM proteins. The present work was undertaken to identify biocompatible fragments of gelatin which are also effective inhibitors of adherence of $C$. albicans to ECM glycoproteins. Fragments of gelatin obtained by treatment of the protein with trypsin or $\mathrm{CNBr}$ were separated and tested individually in a systematic fashion to detect their effect on the adherence of yeast cells to ECM proteins.

\section{METHODS}

Trypsin digestion. Porcine gelatin (Sigma) $\left(1 \mathrm{mg} \mathrm{ml}^{-1}\right)$ in Earle's balanced salt solution (EBSS) containing $10^{-7} \mathrm{M}$ trypsin (Sigma) was incubated for varying times at $37^{\circ} \mathrm{C}$ as stated. Digestion was stopped with twofold excess amounts of soybean trypsin inhibitor (Sigma). Tryptic gelatin fragments were desalted on a Biogel P-2 (Bio-Rad) column, lyophilized, dissolved in $0 \cdot 1 \mathrm{M}$ acetic acid and then separated on a Sephadex 
G-25, G-50 or G-100 (Sigma) column $(2.5 \times 95 \mathrm{~cm})$ equilibrated with $0 \cdot 1 \mathrm{M}$ acetic acid.

CNBr treatment. Porcine gelatin was first reduced by solubilizing $100 \mathrm{mg}$ gelatin in $15 \mathrm{ml} 0.1 \mathrm{M}$ ammonium bicarbonate to which $7 \mathrm{ml} 2$-mercaptoethanol was added. The gelatin was placed in a waterbath overnight at $60^{\circ} \mathrm{C}$. The gelatin was desalted by passage over a Biogel P-2 (Bio-Rad) column in $0 \cdot 1 \mathrm{M}$ acetic acid and lyophilized. Equal amounts of gelatin $(100 \mathrm{mg})$ and $\mathrm{CNBr}(100 \mathrm{mg})$ in $0.1 \mathrm{M} \mathrm{HCl}(20 \mathrm{ml})$ were then incubated at $40^{\circ} \mathrm{C}$ for $4 \mathrm{~h}$. This was desalted on a Biogel P-2 column into $0 \cdot 1 \mathrm{M}$ acetic acid and lyophilized. The lyophilized CNBr-treated gelatin fragments were dissolved in $6 \mathrm{ml} 0.1 \mathrm{M}$ acetic acid and applied to a Sephadex G-100 column.

Separation of CNBr-treated gelatin fragments. Four peaks of CNBr-treated gelatin fragments were identified from the G-100 column. The fractions from the four peaks were pooled, lyophilized, solubilized in EBSS at $1 \mathrm{mg} \mathrm{ml}^{-1}$ concentration and individually tested for adherence inhibitory activity. Peaks from the G-100 column were then separated further by reversedphase HPLC (Gilson, Model 260) using a $0.45 \times 25 \mathrm{~cm} \mathrm{C} C_{18}$ large-pore column (Vydac) with a water/acetonitrile gradient. Mobile phase A consisted of $0.1 \%$ trifluoroacetic acid in distilled water whereas mobile phase B consisted of acetonitrile/ water/trifluoroacetic acid $(95: 4 \cdot 9: 0 \cdot 1$, by vol.). Flow was constant at $1 \mathrm{ml} \mathrm{min}^{-1}$ and the linear gradient at injection was $98 \%$ phase $\mathrm{A}, 2 \%$ phase $\mathrm{B}$, at $30 \mathrm{~min} 78 \% \mathrm{~A}, 22 \% \mathrm{~B}$ and at $40 \mathrm{~min} 38 \% \mathrm{~A}, 62 \% \mathrm{~B}$. The solvent was evaporated from the fractions with dry $\mathrm{N}_{2}$ and the fractions stored at $4{ }^{\circ} \mathrm{C}$.

C. albicans. Four clinical isolates of $C$. albicans were maintained on Sabouraud dextrose agar (Difco) slants and subcultured monthly. For purposes of an adherence assay a loopful of microorganisms from the slant was inoculated into $50 \mathrm{ml}$ Sabouraud dextrose broth (Difco) and incubated at room temperature with shaking for $20 \mathrm{~h}$. This yields early-stationary phase yeast cells. Yeast cells were then washed in EBSS by centrifugation and resuspended at desired concentrations by use of a haemocytometer (Klotz \& Smith, 1991).

Adherence test. The adherence assay was conducted as previously described by Klotz \& Smith (1991). Target proteins were coated onto the bottom of the plastic wells of 24-well tissue culture trays. Bovine corneal subendothelial ECM in 24-well tissue culture trays was purchased from Accurate Chemical and Scientific Corporation. Each well was inoculated with 150 c.f.u. of $C$. albicans in $200 \mu \mathrm{l}$ EBSS with or without protein fragments and left stationary at $37^{\circ} \mathrm{C}$ for $30 \mathrm{~min}$. The number of c.f.u. added was determined by also spreading samples onto Mycosel agar (BBL Laboratories) plates and counting the c.f.u. the following day. The wells were then washed three times with $1 \mathrm{ml}$ EBSS, covered with molten Mycosel agar and incubated overnight at $37^{\circ} \mathrm{C}$. The number c.f.u. in each well was determined the following day and the percentage adherence was calculated by dividing this number by the number c.f.u. added to each well and multiplying by 100 .

Protein sequencing. Peaks obtained from HPLC were submitted for protein sequencing by Edman degradation (Biotechnology Services, University of Kansas Medical Center, Kansas City, KS, USA).

\section{RESULTS}

\section{Trypsin digest}

Digestion of gelatin was first carried out using trypsin solubilized in EBSS, a buffer which allows for maximal adherence of yeast cells to immobilized ECM substrates.
Table 1. The inhibitory activity of non-fractionated trypsin-digested gelatin fragments on the adherence of C. albicans to immobilized gelatin

Percentage adherence equals number of c.f.u. of yeast cells adherent to gelatin as a percentage of the total c.f.u. added. Proteins were added at $1 \mathrm{mg} \mathrm{ml}^{-1}$ concentration. Four wells were used for each experimental variable and the experiments repeated a minimum of three times. Digestion of the protein was at $37^{\circ} \mathrm{C}$.

\begin{tabular}{|lc|}
\hline Addition to gelatin & $\begin{array}{c}\text { Percentage } \\
\text { adherence } \pm \text { SEM }\end{array}$ \\
\hline Buffer only & $87 \pm 4$ \\
Trypsin + trypsin inhibitor & $72 \pm 7$ \\
(added simultaneously, no digestion) & $73 \pm 8$ \\
Trypsin for 60 min, then trypsin inhibitor & $25 \pm 5$ \\
Trypsin for $24 \mathrm{~h}$, then trypsin inhibitor & $22 \pm 6$ \\
Trypsin for $48 \mathrm{~h}$, then trypsin inhibitor & \\
\hline
\end{tabular}

The digestion was terminated at various time points including zero time of incubation and 24 and $48 \mathrm{~h}$ at $37^{\circ} \mathrm{C}$. The results of measuring adherence to immobilized gelatin when the crude digest of gelatin was added simultaneously with yeast cells are shown in Table 1 . As can be seen, by $24 \mathrm{~h}$ digestion the crude trypsin digest was effective in inhibiting the adherence of yeast cells to immobilized gelatin. In order to test the generality of this inhibitory effect by gelatin fragments, digests were added simultaneously with yeast cells to a variety of immobilized ECM proteins. The results of such an experiment are shown in Table 2. Again it is clear that the gelatin fragments inhibit the ability of the yeast cells to adhere to various ECM glycoproteins.

The crude digest obtained in the manner explained above was then passed over a G-25 column and fractions pooled, lyophilized, dissolved in EBSS at $1 \mathrm{mg} \mathrm{ml}^{-1}$ concentrations and the adherence of $C$. albicans yeast cells to type I collagen determined. The inhibitory activity of the crude gelatin digest was contained in the earliest eluting fractions from the G-25 column (data not shown).

\section{CNBr digests of gelatin}

We also analysed $\mathrm{CNBr}$ digests to determine if the same inhibition of yeast cell adherence held true for gelatin fragments produced by this method. The results of Sephadex G-100 chromatography of reduced, CNBrdigested porcine gelatin is shown in Fig. 1. The fractions were pooled from each of the four peaks, lyophilized and tested at $1 \mathrm{mg} \mathrm{ml}^{-1}$ concentrations in the yeast cell adherence assay. This was done in order to identify any inhibitory activity of the pooled samples to immobilized gelatin. The results are shown in Table 3. It is clear that peak 4 possessed significant inhibitory activity in the adherence assay. Therefore peak 4 from the Sephadex G100 chromatography was separated further by reversedphase HPLC using a $\mathrm{C}_{18}$ column and an acetonitrile/water gradient. Over 20 HPLC sample peaks were then in- 
Table 2. Inhibition of adherence of $C$. albicans yeast cells to ECM proteins in the presence of unfractionated trypsin digests of gelatin added at $1 \mathrm{mg} \mathrm{ml}^{-1}$ concentration

Four wells were used for each experimental variable and experiments were repeated a minimum of three times.

\begin{tabular}{|lrrcrr|}
\hline $\begin{array}{l}\text { Yeasts added } \\
\text { to wells in: }\end{array}$ & \multicolumn{4}{c|}{ Percentage of yeasts adhering to proteins \pm SEM } \\
\cline { 2 - 6 } & $\begin{array}{r}\text { Type IV } \\
\text { collagen }\end{array}$ & $\begin{array}{c}\text { Type I } \\
\text { collagen }\end{array}$ & Fibronectin & Laminin & Gelatin \\
\hline $\begin{array}{l}\text { Buffer } \\
\begin{array}{l}\text { Buffer plus } \\
\text { trypsin digest }\end{array}\end{array}$ & $90 \pm 4$ & $79 \pm 1$ & $90 \pm 10$ & $94 \pm 1$ & $88 \pm 5$ \\
\hline
\end{tabular}

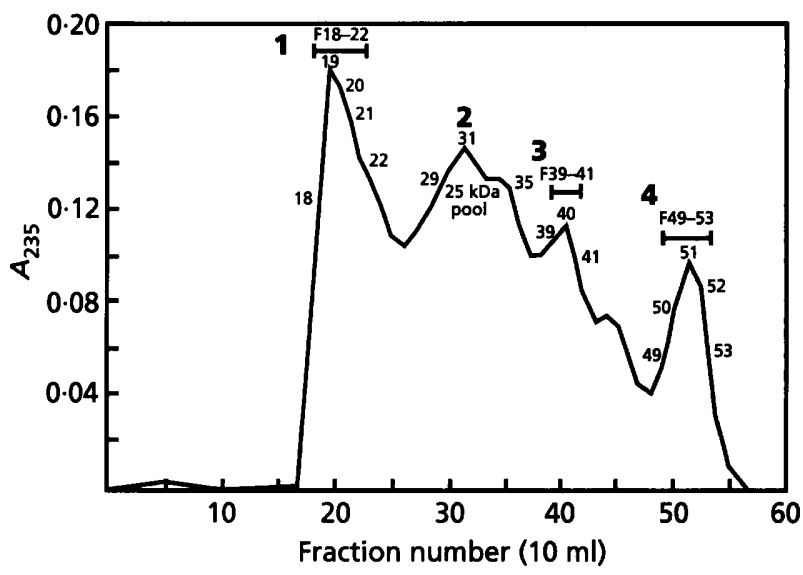

Fig. 1. Peaks and their respective fractions obtained from chromatography of CNBr-digested gelatin on Sephadex G-100.

Table 3. Inhibition of $C$. albicans adherence to immobilized gelatin in the presence of $\mathrm{CNBr}$ digests as separated on a Sephadex G-100 column

Four wells were used for each experimental variable and experiments were repeated a minimum of three times.

\begin{tabular}{|lc|}
\hline Competitive inhibitor & $\begin{array}{c}\text { Percentage } \\
\text { adherence } \pm \text { SEM }\end{array}$ \\
\hline Buffer only & $90 \pm 2$ \\
Undigested gelatin $\left(1 \mathrm{mg} \mathrm{ml}^{-1}\right)$ & $82 \pm 5$ \\
Peak 1 $\left(1 \mathrm{mg} \mathrm{m}^{-1}\right)$ & $79 \pm 3$ \\
Peak 2 $\left(1 \mathrm{mg} \mathrm{ml}^{-1}\right)$ & $72 \pm 3$ \\
Peak 3 $\left(1 \mathrm{mg} \mathrm{ml}^{-1}\right)$ & $74 \pm 4$ \\
Peak 4 $\left(1 \mathrm{mg} \mathrm{ml}^{-1}\right)$ & $22 \pm 2$ \\
\hline
\end{tabular}

dividually lyophilized and resuspended in $200 \mu \mathrm{l}$ buffer and an adherence assay performed. Table 4 shows results from six active peaks. The parent molecule gelatin, as
Table 4. Inhibition of adherence of $C$. albicans to immobilized gelatin in the presence of peptides isolated by HPLC from peak 4 in Fig. 1

Total protein in each dried peak was used in the assay, and was quantified from the area under each peak which, in turn, was related to the areas of peaks collected on a separate chromatogram of this material and measured by the Pierce BCA protein assay using gelatin as standard. The experiments were repeated twice.

\begin{tabular}{|c|c|c|}
\hline Added protein or peak & Protein $(\boldsymbol{\mu g})$ & $\begin{array}{l}\text { Percentage } \\
\text { adherence }\end{array}$ \\
\hline EBSS (control) & - & 100 \\
\hline Gelatin $\left(1 \mathrm{mg} \mathrm{m}^{-1}\right)$ & 200 & 100 \\
\hline Peak 12 & $5 \cdot 5$ & 5 \\
\hline 13 & $6 \cdot 6$ & 6 \\
\hline 14 & 8.5 & 7 \\
\hline 15 & $9 \cdot 6$ & 0 \\
\hline 16 & $5 \cdot 5$ & 3 \\
\hline 17 & $4 \cdot 4$ & 4 \\
\hline
\end{tabular}

shown before, does not have inhibitory activity against yeast cell adherence.

\section{Identification of peptide fragments}

Attempts were made to sequence the proteins in the peaks obtained from reversed-phase HPLC which contained adherence inhibition properties. This was unsuccessful with one exception, mainly because several peptides were found in each peak. The one identified gelatin peptide with $100 \%$ inhibitory properties was a 47 -mer known as CB4, residues $40-86$ of the $\alpha-1$ chain of type I collagen. CB4 contains three RGX sequences but no RGE or RGD sequences. Because we could not purify the peptides from the $\mathrm{CNBr}$ digest to absolute purity we turned to synthesizing several known peptide sequences with possible inhibitory activity. We used several known peptide sequences from the $\alpha-1$ chain of type I collagen in adherence assays (Table 5). Only the 10-mer (residues 
Table 5. Inhibition of adherence of C. albicans to immobilized gelatin by two peptides from the $\alpha-1$ chain of type I collagen, a 9-mer which is the first nine residues of the $\mathrm{N}$-terminus of processed type I collagen, and a $\sim 23$-mer peptide, PepTite-2000, containing the RGD site of fibronectin

Peptides were added to EBSS at $1 \mathrm{mg} \mathrm{ml}^{-1}$ concentrations.

\begin{tabular}{|lc|}
\hline Peptide & $\begin{array}{c}\text { Percentage } \\
\text { adherence } \\
\text { of control }\end{array}$ \\
\hline $\begin{array}{l}\text { PQGIAGQRGVVGLPG-NH } \\
\text { (residues 773-787) }\end{array}$ & 100 \\
GQRGVVGLPG-NH & \\
QLSYGYDEK (residues 778-787) & 32 \\
XXXGRGDSPASSKXXX (PepTite-2000) & 100 \\
\end{tabular}

778-787) demonstrated significant inhibition of adherence whereas several other peptides did not.

\section{DISCUSSION}

The purpose of this study was to identify biocompatible, non-antifungal peptides which block the adherence of $C$. albicans yeast cells to ECM glycoproteins. ECM and its constituent glycoproteins comprise some of the major targets of adherence of this fungus to host tissue (Klotz, 1992) and adherence is one of several acknowledged important steps in the process of establishing disease with the fungus (Calderone \& Braun, 1991). Based on our previous in vitro experiments it was reasonable to conclude that the ability of a protein to block adherence may have potential in ameliorating or abrogating disease with this micro-organism (Klotz \& Smith, 1991). In fact, one in vivo investigation by us supports the concept that blocking adherence ameliorates disease with $C$. albicans (Klotz et al., 1992).

Gelatin cleavage products are good candidates for effective blocking agents for the following reasons. Gelatin itself has little or no inhibitory activity against yeast cell adherence although when immobilized it is a surface to which C. albicans will adhere (Klotz, 1990). In work with fibronectin we learned that whole fibronectin and the amino acid sequences RGD and RGE were effective in inhibiting adherence of $C$. albicans yeast cells to immobilized ECM (Klotz \& Smith, 1991) and cryptogenic fragments of fibronectin derived by enzymic digestion bound more avidly to yeast cells than did whole plasma fibronectin (Penn \& Klotz, 1994).

Gelatin contains both RGD and RGE sequences and therefore its constituent peptides have the theoretical potential to inhibit adherence at least as well as the fibronectin peptides. Furthermore, gelatin is biocompatible (Adelmann-Grill, 1981) and has no detectable antifungal properties. From the work reported here it is obvious that peptides derived from gelatin do inhibit the adherence of $C$. albicans to ECM and ECM proteins. This was apparent from results obtained in adherence experiments using the crude digests of gelatin obtained from digestion with trypsin and $\mathrm{CNBr}$. Furthermore, when $\mathrm{CNBr}$ digests were further separated by column chromatography with Sephadex G-100 into peptides of differing molecular mass it was apparent that the latereluting fractions presumably containing the lower molecular mass peptides possessed the ability to block adherence of the fungus to ECM and its proteins. Upon separation of the fraction responsible for the inhibition of adherence using HPLC it became apparent that several of the lower molecular mass peptides had significant adherence inhibitory properties. The inhibition of adherence by the peptides was extremely effective: very small amounts of the peptides separated by HPLC caused complete inhibition of adherence of $C$. albicans yeast cells to ECM glycoproteins.

Attempts to sequence the peptides responsible for the inhibitory activity were unsuccessful, with one exception, a 47-mer. Therefore several known short peptide sequences derived from the $\alpha-1$ chain of type I collagen were synthesized and tried in the adherence assay. Only one, a 10-mer, showed significant inhibitory activity, but its activity was not comparable to that seen with the 47-mer. Future work will be directed towards improved isolation of these inhibitory proteins in greater quantity as well as defining their exact amino acid sequence.

\section{ACKNOWLEDGEMENTS}

This research was supported by the Veterans Affairs Merit Review programme.

\section{REFERENCES}

Adelmann-Grill, B. C. (1981). Independence of reciprocal attachment sites on denatured collagen and fibronectin from antigenic sites, and binding of gelatin-based plasma substitutes to plasma fibronectin. Collagen Relat Res 1, 367-375.

Calderone, R. A. \& Braun, P. C. (1991). Adherence and receptor relationships of Candida albicans. Microbiol Rev 55, 1-20.

Klotz, S. A. (1990). Adherence of Candida albicans to components of the subendothelial extracellular matrix. FEMS Microbiol Lett 68, 249-254.

Klotz, S. A. (1992). Fungal adherence to the vascular compartment: a critical step in the pathogenesis of disseminated candidiasis. Clin Infect Dis 14, 340-347.

Klotz, S. A. \& Smith, R. L. (1991). A fibronectin receptor on Candida albicans mediates adherence of the fungus to extracellular matrix. $J$ Infect Dis 163, 604-610.

Klotz, S. A., Smith, R. L. \& Stewart, B. W. (1992). Effect of an arginine-glycine-aspartic acid-containing peptide on hematogenous candidal infections in rabbits. Antimicrob Agents Chemother 36, 132-136.

Penn, C. \& Klotz, S. A. (1994). Binding of plasma fibronectin to Candida albicans occurs through the cell binding domain. Microb Pathog 17, 387-393. 